\title{
PENINGKATAN KEMAMPUAN BERPIKIR KRITIS MATEMATIS PESERTA DIDIK DENGAN MENGGUNAKAN STRATEGI REACT
}

\author{
Syaeful Hidayat ${ }^{1}$, Yayan Carlian ${ }^{2}$, Siti Khozanatu Rohmah ${ }^{3}$ \\ Universitas Islam Negeri Sunan Gunung Djati Bandung ${ }^{1,2,3}$ \\ Email: saefulhidayat090998@gmail.com¹,yayan.carlian@uinsgd.ac.id², \\ stkhr2191@gmail.com³
}

Submit: 14 April 2020, Revisi: 7 Juni 2020, Approve: 13 November 2020

\begin{abstract}
This research based on the lows ability of students' mathematical critical thinking skills. The average of preliminary study result is 26.5 . This research aims to describe the enhancement of students' mathematical critical thinking skills who obtain learning using the REACT strategy. The research method is a quasi-experimental method with the nonequivalent pretestposttest control group design. The population of this research is MIS Miftahul Huda students, which amounts to 18 classes and only two classes used for the sample, there are VA and VB. Researcher used purposive sampling for the sampling. The test used for data collection technique, the results of that test will be analyzed by statistical test, there are normality test, homogeneity test, and hypothesis test. The results of the study show that the enhancement of students' mathematical critical thinking skills on scale subject in the class experiment is significantly better than the class control. This result showed from the average $\mathrm{N}$-gain or the enhancement in class experiment was 0.49 while the class control was 0.26 . The average results of class experiment posttest was 55.0 while the average result in class control was 40.8 . So it can be concluded that the REACT strategy is significantly can improve students' mathematical critical thinking skills of MI students.
\end{abstract}

Keywords: Mathematical Critical Thinking Skills, REACT Strategy, Scale

Pengutipan: Syaeful Hidayat, dkk. (2020). Peningkatan Kemampuan Berpikir Kritis Matematis Peserta Didik dengan Menggunakan Strategi REACT. JMIE: Journal of Madrasah Ibtidaiyah Education,4(2), 2020, 175-196. jmie.v4i2.163.

Permalink/DOI: http:/ /dx.doi.org/10.32934/jmie.v4i2.163 


\section{PENDAHULUAN}

Pendidikan adalah sebuah usaha yang disadari dan direncanakan, serta diberikan dari orang dewasa kepada generasi muda demi terwujudnya suatu proses pembelajaran dan suasana belajar yang aktif sehingga peserta didik mampu mengembangkan potensinya (Yahya, 2010; Hamdani, 2011). Potensi-potensi tersebut diantaranya: olahraga, keagamaan, kesenian, akhlak, serta kecerdasan seluruh anak bangsa. Maka dengan pendidikan seseorang diharapkan mampu mengembangkan seluruh potensinya dan dapat menghadapi permasalahan dalam kehidupan.

Salah satu ilmu pendidikan yang menjadi dasar dalam berkembangnya kemajuan teknologi yaitu matematika (Suandito, 2017). Matematika dapat mengembangkan potensi daya nalar kemampuan berpikir (Suandito, 2017). Selain itu, matematika dalam cara berpikir memiliki format yang terstruktur dan pembelajaran matematika ini menghubungkan antar konsep yang kompeten dalam matematika sehingga menjadikan peserta didik mampu mengembangkan pemikirannya sesuai perkembangan zaman yaitu pada era reformasi abad 21 (Johar, 2013). Keterampilan pembelajaran pada pendidikan di era industri 4.0 (abad 21) salah satunya adalah critical-thinking atau berpikir kritis (Abidin, 2015). Pentingnya critical-thinking yaitu mampu membuat keputusan dan mempertanggungjawabkannya serta keputusan tersebut memerlukan informasi yang terpercaya sehingga seseorang akan melakukannya dengan sungguh-sungguh (Abdullah, 2013).

Kemampuan berpikir kritis pada era reformasi saat ini memang sangat diperlukan dalam pembelajaran matematika (Ratna Purwati, Hobri, 2016). Melalui pembelajaran matematika, kemampuan berpikir kritis matematis peserta didik akan diperoleh (Paradesa, 2016). Adanya pembelajaran matematika di kelas menjadikan peserta didik menjadi mampu memecahkan permasalahan, mengambil serta memutuskan keputusan dengan logis. Sehingga berpikir kritis itu sangat penting dimiliki oleh setiap peserta didik, mengingat perkembangan ilmu serta tenologi yang sangat berkembang. Hasil Trends in Mathematic and Science Study (TIMSS) edisi terbaru pada tahun 2018, peringkat Indonesia berada di urutan 73 dari 79 negara dengan nilai rata-rata 379 pada kategori matematika (Kemendikbud, 2017).

Berdasarkan pernyataan tersebut, sudah seharusnya peserta didik meningkatkan kemampuan bernalarnya. Salah satunya dengan meningkatkan kemampuan berpikir kritis, sebab kemampuan tersebut menurut Kurlik dan Rudnick (Utami, 2013) merupakan bagian dari bernalar. Apabila hal tersebut dibiarkan, maka akan mengakibatkan lulusan pendidikan di negara kita kurang mampu mengimplementasikan ilmu yang didapat dibangku sekolah dengan kehidupan sehari-hari yang dialami dan menghadapi permasalahan lainnya (Adiwijaya, 2015). Proses aktif dan teliti juga merupakan pengertian dari proses berpikir kritis (Abidin, 2015). Maksudnya dalam keterampilan berpikir kritis peserta didik harus memahami dan mengevaluasi sebuah informasi dan ketika informasi tersebut masuk atau datang peserta didik harus mampu memikirkan terlebih dahulu secara mendalam agar dapat membuat suatu kesimpulan. 
Tidak hanya itu, berdasarkan studi pendahuluan hasilnya menunjukkan bahwa sebagian besar peserta didik masih rendah dalam kemampuan berpikir kritis matematisnya. Hanya 1 dari 28 orang peserta didik yang memenuhi kriteria kelulusan pada tes yang diberikan peneliti. Studi pendahuluan dilakukan dengan pemberian tes berupa soal uraian mengenai materi volume kubus dan balok yang sesuai dengan indikator kemampuan berpikir kritis matematis yang diberikan kepada peserta didik kelas V. Ketika menjawab soal, terlihat beberapa peserta didik sebenarnya memahami soal yang diberikan tetapi mengalami kesulitan dalam hal memberikan penjelasan sederhana. Jawabannya di atas menunjukkan bahwa peserta didik sudah bisa memahami soal yang diberikan, namun untuk menjelaskan secara sederhana peserta didik masih merasa kesulitan. Bahkan peserta didik belum bisa mengerjakan secara sistematis. Selain itu, berdasarkan wawancara kepada guru kelas $\mathrm{V}$ mengenai pembelajaran matematika yang terjadi saat proses pembelajaran. Beliau mengatakan bahwa ketika ketika proses pembelajaran peserta didik masih kurang dalam hal mengaplikasikan materi ke dalam kehidupan sehari-hari. Mereka senang ketika diberikan materi seperti perkalian yang dianggap mudah oleh mereka, akan tetapi ketika diaplikasikan merasa kesulitan.

Proses mengajar yang sudah dilaksanakan oleh pendidik sudah cukup bagus pada saat pendidik melakukan pembelajaran dengan memakai metodologi pembelajaran. Hanya saja metodologi pembelajaran yang digunakan kurang bervariatif. Pembelajaran sering menggunakan model pembelajaran konvensional, sehingga peserta didik kurang dalam mengembangkan kemampuannya khususnya berpikir kritisnya. Ketika proses belajar mengajar dilaksanakan, pendidik lebih banyak mendominasi ketika pembelajaran dan menjadikan peserta didik menjadi tidak kondusif ketika proses pembelajaran berlangsung (Devi, 2015).

Pembelajaran matematika bukan hanya transfer of knowledge tetapi perlu peran aktif peserta didik sebagai subjek dalam belajar (Suherman, p. 2011). Guru dan peserta didik memiliki peran penting dalam tercapainya tujuan pembelajaran. Oleh karena itu, ketika proses pembelajaran perlu diterapkan strategi yang tepat, supaya materi pelajaran dapat tersampaikan dan tujuan pembelajaran dapat tercapai. Pemilihan strategi ini harus mempertimbangkan segalanya, mulai dari kondisi peserta didik, suasana dikelas bahkan sampai pembelajaran sebelumnya yang sudah diterapkan.

Salah satu strategi pembelajaran yang bisa diterapkan agar dapat meningkatkan kemampuan peserta didik dalam berpikir kritis adalah strategi REACT. REACT yaitu relating (mengaitkan) adalah mengaitkan/menghubungkan materi dengan pengalaman peserta didik yang sudah mereka alami atau dari pengetahuan yang telah mereka dapatkan. Experiencing (mengalami) adalah peserta didik dituntut untuk dapat mengalami secara langsung kemudian menemukan dan mengolah sendiri sehingga menjadi suatu penemuan baru yang sesuai dengan pengalamannya. Applying (menerapkan) adalah memanfaatkan kehidupan yang telah dialaminya untuk menerapkan konsep matematika yang telah diperoleh. Cooperating (bekerjasama) adalah suatu proses pembelajaran yang dirancang berkelompok untuk berdiskusi memecahkan suatu 
masalah yang anggotanya terdiri 4-5 orang. Transfering (mentransfer) adalah sebagai penggunaan pengetahuan yang sudah peserta didik dapatkan ketika proses pembelajaran ke dalam situasi yang baru. (Pusipta Aini, Firda Nurul, Suprakarti, 2015)

Berdasarkan permasalahan tersebut, rumusan yang diangkat oleh peneliti adalah (1) Bagaimana kemampuan awal berpikir kritis matematis peserta didik MI Kelas V pada kelas eksperimen dan kelas kontrol? (2) Apakah peningkatan kemampuan berpikir kritis peserta didik MI kelas $\mathrm{V}$ yang memperoleh pembelajaran di kelas eksperimen lebih baik dari peserta didik yang memperoleh pembelajaran di kelas kontrol?".

Pendekatan kontekstual adalah suatu pembelajaran mengaitkan ilmu yang dipelajari di bangku sekolah dan mengimplementasikannya dengan kehidupan nyata peserta didik (Syahbana, 2012). Pendekatan kontekstual tentunya memiliki beberapa komponen yang harus dipenuhi, diantaranya kontruktivisme, bertanya, menemukan, masyarakat belajar, pemodelan, refleksi, dan penilaian autentik (Depdiknas, 2013). Kemudian pendekatan kontekstual juga menekankan pada keterlibatan peserta didik secara utuh dan menerapkannya dalam khidupan sehari-hari. Hal tersebut sangat sesuai dengan strategi REACT dan mampu meningkatkan kemampuan berpikir kritis peserta didik.

REACT merupakan bagian dari pendekatan kontekstual yang dimana peserta didik difokuskan untuk memperoleh pemahamannya sendiri dan tugas pendidik mengajarkan cara mendapakatkan pemahaman tersebut dari pengalaman (Durotulaila et al., 2014). Strategi REACT mempunyai lima tahapan strategi pembelajaran dalam REACT diantaranya: relating (mengaitkan) adalah mengaitkan/menghubungkan materi dengan pengalaman peserta didik yang sudah mereka alami atau dari pengetahuan yang telah mereka daparkan. Experiencing (mengalami) adalah peserta didik dituntut untuk dapat mengalami secara langsung kemudian menemukan dan mengolah sendiri sehingga menjadi suatu penemuan baru yang sesuai dengan pengalamannya. Applying (menerapkan) adalah memanfaatkan kehidupan yang telah dialaminya untuk menerapkan konsep matematika yang telah diperoleh. Cooperating (bekerjasama) adalah suatu proses pembelajaran yang diseting berkelompok untuk berdiskusi memecahkan suatu masalah yang anggotanya terdiri 4-5 orang. Transfering (mentransfer) adalah sebagai penggunaan pengetahuan yang sudah peserta didik dapatkan ketika proses pembelajaran KE DALAM situasi yang baru.

Berpikir kritis merupakan hasil dari proses pembelajaran yang dialami oleh peserta didik dengan bertujuan untuk menciptakan suatu keputusan dan akan dilaksanakan (Paradesa, 2016). Kemampuan berpikir kritis akan tercapai salah satunya dengan pemberian tes tertulis berupa Lembar Kerja Peserta Didik (LKPD) kepada peserta didik. Indikator kemampuan berpikir ktitis mengacu pada teori Ennis (Yudhanegara, 2017) yaitu memberikan penjelasan sederhana (elementary clarification); Membangun keterampilan dasar (basic support); Membangun simpulan 
(inference); Membuat penjelasan lebih lanjut (advances clarification); Menentukan strategi dan taktik (strategi and tactics) untuk menyelesaikan masalah.

Penelitian relevan yang dijadikan dasar diantaranya (1) Penelitian yang dilakukan oleh Mahmud (2011) dengan judul "Pembelajaran Kontekstual Strategi REACT (Relating, Experiencing, Applying, Cooperating, Transferring) untuk Meningkatkan Kemampuan Pemahaman Matematika Peserta didik". Hasil penelitian menunjukkan strategi REACT dapat meningkatkan kemampuan pemahaman matematika peserta didik pada pokok bahasan bangun datar segi empat yang terdiri dari persegi panjang, persegi, jajargenjang, belah ketupat, layang-layang, dan trapesium. (2) Penelitian yang dilakukan oleh Pratiwi (2014) dengan judul penelitian "Penerapan Strategi REACT untuk Meningkatkan Kemampuan Komunikasi Matematis Peserta didik Sekolah Dasar Materi Bangun Ruang Sederhana". Hasil penelitian menunjukkan bahwa strategi REACT dapat meningkatkan kemampuan komunikasi matematis pada peserta didik kelas IV SDN 1 Cibogo Kecamatan Lembang Kabupaten Bandung Barat materi bangun ruang sederhana. (3) Penelitian yang dilakukan oleh Rahmaton (2018) dengan judul penelitian "Meningkatkan Kemampuan Berpikir Kritis Matematis Melalui Strategi REACT pada peserta didik kelas VII MTSN 6 Aceh Besar”. Hasil Penelitian menunjukkan bahwa strategi REACT dapat meningkatkan kemampuan berpikir kritis matematis peserta didik kelas VII MTSN 6 Aceh Besar materi persamaan dan pertidaksamaan linear satu variabel.

Persamaan penelitian yang telah ada dengan yang dilakukan oleh penulis terdapat pada variabel X yang sama-sama menggunakan strategi pembelajaran REACT. Selain itu, variabel Y dalam beberapa penelitian yang telah diuraikan pun memiliki persamaan yaitu mengenai kemampuan berpikir kritis matematis peserta didik. Namun, penelitian yang akan dilakukan penulis berbeda dari penelitian yang sudah ada. Meskipun kemampuan yang diukur sama yaitu mengenai kemampuan berpikir kritis matematis, namun yang dipakai oleh penulis berbeda yaitu: (1) Memberikan penjelasan sederhana (elementary clarification); (2) Membangun keterampilan dasar (basic support); (3) Membangun simpulan (inference). Perbedaan lainnya yaitu pada objek penelitian penulis yaitu peserta didik kelas $\mathrm{V}$.

Peneliti mengharapkan dengan adanya penelitian mengenai kemampuan berpikir kritis pada peserta didik ditingkat dasar khususnya MI. Peserta didik mampu mengembangkan pemikirannya dengan kritis dan memperdalam tentang ilmu yang diperoleh serta peserta didik mampu bersaing dengan peserta didik lainnya.

\section{METODE PENELITIAN}

Metode yang digunakan dalam penelitian ini adalah metode kuasi eksperimen. Kuasi eksperimen memiliki beberapa desain, dan desain yang digunakan dalam penelitian ini adalah The Nonequivalent Pretest-Posttest Control Group Design. Desain ini memiliki kesamaan dengan desain pretest-posttest control group design dari metode eksperimen murni (Sugiyono, 2017). Perbedaannya 
adalah tidak adanya pemilihan sampel random untuk kelas eksperimen maupun kontrol. Pemilihan kelas eksperimen dan kelas kontrol dilakukan dengan menggunakan kelas yang sudah ada (Purposive sampling). Penelitian Eksperimen khususnya pada kuasi eksperimen memperbolehkan jika peserta didik tidak dikelompokkan secara acak/random (Ruseffendi, 2010). Variabel bebas dari penelitian ini yaitu penerapan strategi REACT, variabel terikatnya yaitu kemampuan komunikasi matematis, dan variabel kontrolnya adalah pokok bahasan skala untuk kelas V MI.

Populasi yang digunakan dalam penelitian adalah MIS Miftahul Huda Kota Bandung yang berjumlah 18 rombel. Sampel yang digunakan hanya dua kelas yaitu kelas V MIS Miftahul Huda. Untuk memilih kelas yang dijadikan kelas eksperimen dan kontrol dilakukan secara acak. Sehingga diperoleh kelas VA sebagai kelas kontrol dan VB sebagai kelas eksperimen.

Teknik pengumpulan data menggunakan tes, Ada dua bagian tes yang digunakan oleh peneliti, diantaranya yang pertama sebelum pemberian materi yang disebut dengan pretest dan kedua setelah pemberian materi yang disebut dengan posttest. Pemberian tes pretest bertujuan untuk melihat kemampuan awal peserta didik pada kedua kelas tersebut. Setelah itu, pemberian posttest yang bertujuan untuk melihat peningkatan pada kedua kelas tersebut setelah diberikan materi terutama yang sudah mendapatkan perlakuan dengan strategi REACT. Adapun tes yang digunakan berbentuk tes uraian. Tes uraian tersebut untuk mengali data pretest dan postest serta mengetahui peningkatan peserta didik. Tes uraian tersebut telah diujicobakan kepada para ahli dalam bidang tersebut dan hasilnya sebagai berikut.

Tabel 1 Rekapitulasi Analisis Hasil Uji Coba Soal

\begin{tabular}{|c|c|c|c|c|c|c|}
\hline No & Validitas & Reliabilitas & DP & & $\mathbf{K}$ & Ket. \\
\hline 1 & 0.639 & \multirow{6}{*}{0.53} & 0.55 & 0,43 & Sedang & Soal dapat digunakan \\
\hline 2 & 0.491 & & 0.18 & 0,15 & Sukar & Soal dapat digunakan \\
\hline 3 & 0.441 & & 0.38 & 0,37 & Sedang & Soal dapat digunakan \\
\hline 4 & 0.550 & & 0.18 & 0,10 & Sukar & Soal dapat digunakan \\
\hline 5 & -0.010 & & 0.02 & 0,04 & Sukar & Soal tidak dapat digunakan \\
\hline 6 & 0.407 & & 0.14 & 0,08 & Sukar & Soal dapat digunakan \\
\hline
\end{tabular}

Berdasarkan tabel analisis yang telah dilakukan, diperoleh hasil bahwa terdapat satu soal yang tidak dapat digunakan untuk pretest dan posttest yaitu pada nomor 5. Maka dari itu peneliti memutuskan untuk menghapus soal tersebut karena soal tersebut indikatornya telah dipenuhi pada soal sebelumnya.

Teknik analisis data menggunakan analisis statistik yaitu uji normalitas, uji homogenitas, uji hipotesis dan N-Gain untuk melihat peningkatan setelah diberikan perlakuan. Tahap-tahap tersebut akan diuraikan sebagai berikut: 
Uji normalitas adalah alah satu uji prasyarat yang harus dilakukan dan bertujuan untuk melihat normal atau tidak normal suatu data. Uji ini juga dapat menentukan langkah uji berikutnya. Uji homogenitas atau uji F (Uji Fisher) untuk melihat kehomogenan kedua daya yang diperoleh, kedua data tersebut diuji homogenitasnyanya apabila kedua data tersebut berdistribusi normal. Uji hipotesis adalah menguji parameter populasi berdasarkan sampel yang digunakan agar dapat disimpulkan secara general. Ada tiga alternatif dalam pengujian hipotesis yaitu (1) Apabila data kedua kelas berdistribusi normal dan homogen maka dilakukan uji t; (2) Apabila Apabila hasil data kedua kelas normal tetapi salah satu atau keduanya tidak homogen, maka dilakukan uji $t^{\prime}$; (3) Apabila hasil data kedua kelas ada salah satu atau keduanya tidak normal, maka tidak perlu dilakukan uji homogenitas. Maka, langsung melakukan perhitungan dengan statistik non parametrik yaitu uji mann whitney. Uji mann whitney adalah uji non parametrik yang digunakan untuk mengetahui perbedaan median dua kelompok bebas tetapi tidak berdistribusi normal. Data N-gain atau Gain ternormalisasi diperoleh dengan membandingkam selisih skor posttes dan pretest dengan selisih SMI dan pretest. Kemudian dari data ini bisa dilihat peningkatan kemampuan peserta didik, serta akan memberi informasi tentang peringkat peserta didik di kelas.

\section{HASIL DAN PEMBAHASAN}

Berdasarkan hasil penelitian yang telah dilakukan mengenai penerapan strategi REACT untuk meningkatkan kemampuan berpikir kritis matematis peserta didik MI, diperoleh hasil sebagai berikut:

1. Kemampuan awal berpikir kritis matematis MI kelas V pada kelas eksperimen dan kelas kontrol.

Kemampuan awal kemampuan berpikir kritis matematis peserta didik kelas V MIS Miftahul Huda diperoleh dari pretest yang diberikan kepada peserta didik sebelum mendapatkan pembelajaran dengan menggunakan strategi REACT untuk kelas eksperimen dan pembelajaran konvensional untuk kelas kontrol. Setelah diperoleh hasil pretest dari kedua kelas, maka yang pertama dilakukan adalah üi normalitas sebagai uji prasyarat.

\section{a. Uji Normalitas One-Sample Kolmogorov-Smirnov}

Melakukan uji nomalitas bertujuan agar mengetahui data tersebut normal atau tidak. Uji normalitas yang digunakan oleh peneliti One-Sample Kolmogorov-Smirnov dengan taraf signifikansi $\alpha=0,05$. Adapun hipotesisnya adalah sebagai berikut.

$\mathrm{H}_{0}$ : hasil pretest kemampuan berpikir kritis matematis berdistribusi normal

$\mathrm{H}_{1}$ : hasil pretest kemampuan berpikir kritis matematis tidak berdistribusi normal 
Dalam mengambil keputusan suatu kesimpulan tentunya ada kategorinya, apaila nilai signifikansi $P$-value $<\alpha$ (taraf signifikansi 0,05$)$ maka $\mathrm{H}_{0}$ ditolak dan apabila nilai sinifikansi $P$-value $\geq \alpha$ (taraf signifikansi 0,05$)$ maka $\mathrm{H}_{0}$ diterima. Berdasarkan hasil analisis dengan memakai software SPSS 20 for windows diperoleh hasilnya sebagai berikut.

Tabel 2 Uji Normalitas Skor Pretest

\begin{tabular}{|c|c|c|c|c|c|}
\hline \multirow{2}{*}{ Kelas } & \multicolumn{3}{|c|}{ Kolmogorov-Smirnov } & \multirow{2}{*}{ Kesimpulan } & \multirow{2}{*}{ Makna } \\
\hline & $\mathbf{N}$ & $\mathrm{Z}$ & $\begin{array}{l}\text { Sig. (2 } \\
\text { pihak) }\end{array}$ & & \\
\hline Ekserimen & 26 & 0,133 & 0,200 & $\mathrm{H}_{0}$ diterima & Berdistribusi normal \\
\hline Kontrol & 21 & 0,230 & 0,005 & $\mathrm{H}_{0}$ ditolak & $\begin{array}{c}\text { Berdistribusi tidak } \\
\text { normal }\end{array}$ \\
\hline
\end{tabular}

Berdasarkan tabel uji normalitas, dapat disimpulkan bahwa hasil pretest kemampuan berpikir kritis matematis peserta didik pokok bahasan skala pada kelas eksperimen untuk diuji normalitas One-Sample Kolmogorov-Smirnov memiliki nilai sig. yang bertututturut 0,200 dan 0,005. Kedua kelas tersebut memiliki signifikansi $\alpha=0,05$. Sehingga untuk kelas eksperimen menjadi 0,200 > 0,05 maka $\mathrm{H}_{0}$ diterima artinya sampel berasal dari populasi yang berdistribusi normal. Sedangkan untuk kelas kontrol menjadi 0,005 < 0,05 maka $\mathrm{H}_{0}$ ditolak artinya sampel berasal dari populasi yang berditribusi tidak normal. Dengan demikian, karena salah satu dari data di atas terdapat data yang tidak normal, maka selanjutnya harus melakukan Uji Mann Whitney.

\section{b. Uji Mann Whitney}

Hasil data pretest telah telah dilakukan sebagai uji prasyarat dengan hasil kelas eksperimen berdistribusi normal dan kelas eksperimen berdistribusi tidak normal. Maka, langkah selanjutnya dilakukan uji mann whitney untuk mengetahui terdapat perbedaan kemampuan atau tidak terhadap dua kelas yang telah diujikan. Adapun hipotesisnya adalah sebagai berikut.

$\mathrm{H}_{0}$ : Tidak terdapat perbedaan rata-rata skor pretest kemampuan berpikir kritis matematis peserta didik sebelum memperoleh pembelajaran dengan strategi REACT dan pembelajaran konvensional.

$\mathrm{H}_{1}$ : Terdapat perbedaan rata-rata skor pretest kemampuan berpikir kritis matematis peserta didik sebelum memperoleh pembelajaran dengan strategi REACT dan pembelajaran konvensional. 
Kriteria pengambilan keputusan ditentukan jika nilai signifikansi $P$-value $<\alpha$ (taraf signifikansi 0,05) maka $\mathrm{H}_{0}$ ditolak dan jika nilai sinifikansi $P$-value $\geq \alpha$ (taraf signifikansi $0,05)$ maka $\mathrm{H}_{0}$ diterima. Berdasarkan hasil perhitungan dengan menggunakan software SPSS 20 for windows diperoleh hasil uji mann whitney data pretest pada tabel berikut.

Tabel 3 Uji Mann Whitney Skor Pretest

\begin{tabular}{cccc}
\hline Skor $\mathbf{Z}$ & dk & Sig. (2 pihak) & Kesimpulan \\
\hline$-2,346$ & 47 & 0,019 & $\mathrm{H}_{0}$ ditolak
\end{tabular}

Berdasarkan tabel uji mann whitney, terlihat bahwa U hitung untuk skor kedua kelompok dengan data yang tidak normal dan tidak homogen adalah -2,346 dan Sig. (2 pihak) sebesar 0,019. Maka, nilai $P$-value yang diperoleh adalah 0,019 lebih kecil dari $\alpha=0,05$, maka $\mathrm{H}_{0}$ ditolak. Artinya pada taraf kepercayaan 95\% dapat disimpulkan bahwa hasil pretest kemampuan berpikir kritis matematis peserta didik sebelum mendapatkan pembelajaran dengan strategi REACT dan pembelajaran konvensional memiliki perbedaan yang signifikan. Dengan demikian hasil pretest tersebut memiliki perbedaan dikarenakan jumlah pada setiap kelas berbeda dan tingkat kemampuan pada setiap kelas juga berbeda.

\section{Peningkatan Kemampuan Berpikir Kritis Matematis Peserta Didik}

Penerapan pembelajaran telah selesai dilaksanakan pada kelas eksperimen menerapkan strategi REACT dan pada kelas kontrol menerapkan pembelajaran konvensional. Selanjutnya diberikan posttest yang bertujuan untuk melihat peningkatan (N-Gain) pada kelas eksperimen dan kelas kontrol.

\section{a. Uji Normalitas One-Sample Kolmogorov-Smirnov}

Melakukan uji nomalitas bertujuan agar mengetahui data tersebut normal atau tidak. Uji normalitas yang digunakan oleh peneliti One-Sample Kolmogorov-Smirnov dengan taraf signifikansi $\alpha=0,05$. Adapun hipotesisnya adalah sebagai berikut.

$\mathrm{H}_{0}$ : hasil N-Gain kemampuan berpikir kritis matematis berdistribusi normal

$\mathrm{H}_{1}$ : hasil N-Gain kemampuan berpikir kritis matematis tidak berdistribusi normal

Dalam mengambil keputusan suatu kesimpulan tentunya ada kategorinya, apaila nilai signifikansi $P$-value $<\alpha$ (taraf signifikansi 0,05$)$ maka $\mathrm{H}_{0}$ ditolak dan apabila nilai sinifikansi $P$-value $\geq \alpha$ (taraf signifikansi 0,05 ) maka $\mathrm{H}_{0}$ diterima. Berdasarkan hasil analisis dengan memakai software SPSS 20 for windows diperoleh hasilnya sebagai berikut. 
Tabel 4 Uji Normalitas Skor Peningkatan (N-Gain)

\begin{tabular}{|c|c|c|c|c|c|}
\hline \multirow[b]{2}{*}{ Kelas } & \multicolumn{3}{|c|}{ Kolmogorov-Smirnov } & \multirow[b]{2}{*}{ Kesimpulan } & \multirow[b]{2}{*}{ Makna } \\
\hline & $\mathbf{N}$ & $\mathrm{Z}$ & $\begin{array}{l}\text { Sig. (2 } \\
\text { pihak) }\end{array}$ & & \\
\hline Eksperimen & 26 & 0,134 & 0,200 & $\mathrm{H}_{0}$ diterima & Berdistribusi normal \\
\hline Kontrol & 21 & 0,181 & 0,070 & $\mathrm{H}_{0}$ diterima & Berdistribusi normal \\
\hline
\end{tabular}

Berdasarkan table uji normalitas, dapat disimpulkan bahwa data hasil N-Gain kemampuan berpikir kritis matematis peserta didik mengenai pokok bahasan skala pada kelas eksperimen memiliki nilai signifikansi 0,200 dan pada kelas kontrol memiliki nilai signifikansi 0,070. Kedua kelas tersebut memiliki nilai signifikansi lebih besar dari $\alpha=$ 0,05 sehingga $\mathrm{H}_{0}$ diterima, artinya data berasal dari populasi yang berdistribusi normal.

b. Uji Homogenitas

Data hasil skor N-Gain setelah dilakukan uji prasyarat yaitu uji normalitas, kedua kelas tersebut berada pada distribusi normal. Sehingga langkah berikutnya yang harus dilakukan yaitu uji homogeitas. Uji homogenitas dilakukan untuk melihat kehomogenan kedua data yang diperoleh. Uji homogenitas dilakukan dengan taraf signifikansi $\alpha=$ 0,05. Adapun hipotesisnya adalah sebagai berikut.

$\mathrm{H}_{0} \quad$ : Tidak terdapat perbedaan variansi skor N-Gain antara kelas eksperimen dan kelas

kontrol.

$\mathrm{H}_{1} \quad$ : Terdapat perbedaan variansi skor N-Gain antara kelas eksperimen dan kelas kontrol.

Kriteria pengambilan keputusan ditentukan jika nilai $P$-value $<\alpha$ (taraf signifikansi 0,05) maka $\mathrm{H}_{0}$ ditolak dan jika nilai sinifikansi $P$-value $\geq \alpha$ (taraf signifikansi 0,05) maka $\mathrm{H}_{0}$ diterima. Berdasarkan hasil perhitungan dengan menggunakan software SPSS 20 for windows diperoleh hasil uji homogenitas data N-Gain pada tabel berikut.

Tabel 5 Uji Homogenitas Skor Peningkatan (N-gain)

\begin{tabular}{ccccc}
\hline Levene Statistic & Dk1 & Dk2 & Sig. & Kesimpulan \\
\hline 0,004 & 1 & 45 & 0,951 & $\mathrm{H}_{0}$ diterima \\
\hline
\end{tabular}


Berdasarkan tabel uji homogenitas, diperoleh nilai $P$-V alue sebesar 0,951. Nilai tersebut lebih besar daripada nilai $\alpha$ yang dipilih, yaitu $\alpha=0,05$. Karena nilai $P-$ value $\geq \alpha$, maka $\mathrm{H}_{0}$ diterima. Dengan demikian, hasil pengujian dengan Levene's test software SPSS 20 for windows tersebut memberikan kesimpulan bahwa hasil tidak terdapat perbedaan variansi skor posttest antara kelas eksperimen dan kelas atau kemampuan berpikir kritis matematis kedua kelas adalah homogen.

c. Uji Perbedaan Rata-rata Skor Peningkatan (N-Gain) Kemampuan Berpikir Kritis Matematis Peserta Didik

Setelah memperoleh data hasil N-Gain pada kedua kelas yang berdistribusi normal dan datanya homogen. Maka, langkah berikutnya adalah melakukan uji t (uji independent t-test). Uji t tersebut dilakukan untuk melihat kemampuan berpikir kritis matematis kedua kelas tersebut. Sesuai dengan hipotesis penelitian yang telah dibuat, maka digunakan hipotesis satu pihak. Hipotesisnya adalah sebagai berikut.

$\mathrm{H}_{0} \quad$ : Tidak terdapat perbedaan rata-rata skor N-Gain kemampuan berpikir kritis matematis peserta didik yang memperoleh pembelajaran matematika dengan strategi REACT dengan peserta didik yang memperoleh pembelajaran konvensional.

$\mathrm{H}_{1} \quad$ : Rata-rata skor N-Gain kemampuan berpikir kritis matematis peserta didik yang memperoleh pembelajaran matematika dengan strategi REACT lebih baik dari pada peserta didik yang memperoleh pembelajaran konvensional.

Kriteria pengambilan keputusan ditentukan jika nilai signifikansi $P$-value $<\alpha$ (taraf signifikansi 0,05) maka $\mathrm{H}_{0}$ ditolak dan jika nilai sinifikansi $P$-value $\geq \alpha$ (taraf signifikansi $0,05)$ maka $\mathrm{H}_{0}$ diterima. Berdasarkan hasil perhitungan dengan menggunakan software SPSS 20 for windows diperoleh hasil uji t data posttest pada tabel berikut.

Tabel 6 Uji t Skor Posttest

\begin{tabular}{cccc}
\hline $\mathbf{t}$ & $\mathbf{d k}$ & Sig. (2 pihak) & Kesimpulan \\
\hline 2,644 & 45 & 0,011 & $\mathrm{H}_{0}$ ditolak
\end{tabular}

Berdasarkan tabel uji t, terlihat bahwa thitung untuk skor kedua kelompok dengan data yang homogen adalah 2,644 dan signifikansi (2 pihak) 0,011. Nilai P-value yang diperoleh kemudian dibagi dua karena penelitian ini menggunakan uji satu pihak. Nilai P-value yang diperoleh adalah $\frac{0,011}{2}$ lebih kecil dari $\alpha=0,05$, maka $H_{0}$ ditolak. Artinya pada taraf kepercayaan 95\% dapat disimpulkan bahwa rata-rata skor N-Gain kemampuan berpikir kritis matematis peserta didik yang memperoleh pembelajaran matematika dengan strategi REACT lebih baik secara signifikan dari pada peserta didik yang memperoleh pembelajaran 
konvensional. Dengan demikian, peningkatan kemampuan berpikir kritis matematis kelas eksperimen peningkatannya lebih baik secara signifikan dari pada kelas kontrol.

Adapun pembahasan dari hasil yang telah diperoleh dari kelas eksperimen dan kelas kontrol adalah sebagai berikut.

a. Kemampuan Awal Berpikir Kritis Matematis

Hasil penelitian ini membahas tentang kemampuan berpikir kritis matematis peserta didik pada kelas eksperimen dan kelas kontrol. Berdasarkan hasil pengolahan dan analisis data pretest, pembahasan dalam penelitian ini adalah secara umum kemampuan peserta didik mengenai pokok bahasan skala sebelum menerapkan pembelajaran dengan strategi REACT dan pembelajaran konvensional adalah berbeda. Hasil uji normalitas pada kedua kelas yang berdistribusi normal untuk kelas eksperimen dan tidak berdistribuis normal untuk kelas kontrol. Pretest diberikan kepada pserta didik yang berjumlah 47 orang yang terdiri dari 26 orang kelas kontrol (kelas VB) dan 21 orang kelas kontrol (kelas VA). Hasil pretest kemampuan berpikir kritis matematis peserta didik dari kedua kelas sebelum memperoleh pembelajaran, berikut tabelnya dapat dilihat di bawah ini.

\section{Tabel 7 Data Hasil Pretest Kemampuan Berpikir Kritis}

\section{Kelas Eksperimen}

\section{Kelas Konrol}

\begin{tabular}{cccccccc}
\hline $\begin{array}{c}\text { Jumlah } \\
\text { Peserta } \\
\text { didik }\end{array}$ & Nilai & Nilai & Rata- & $\begin{array}{c}\text { Jumlah } \\
\text { Peserta } \\
\text { didik }\end{array}$ & $\begin{array}{c}\text { Nilai } \\
\text { Min. }\end{array}$ & $\begin{array}{c}\text { Nilai } \\
\text { Max. }\end{array}$ & $\begin{array}{c}\text { Rata- } \\
\text { rata }\end{array}$ \\
\hline 26 & 0 & 53 & 14,2 & 21 & 0 & 40 & 20,7 \\
\hline
\end{tabular}

Berdasarkan tabel data tersebut, rata-rata hasil pretest peserta didik pada kelas eksperimen sebelum memperoleh pembelajaran dengan strategi REACT sebesar 14,2 termasuk kategori jelek. Rata-rata hasil pretest peserta didik pada kelas kontrol sebelum memperoleh pembelajaran konvensional sebesar 20,7 termasuk kategori jelek.

Peneliti menjabarkan pada setiap indikator kemampuan berpikir kritis peserta didik dengan nilai berkisar 1-4 pada setiap indikatornya memang sangat kurang. Indikator pertama rata rata kedua kelas eksperimen dan kontrol berturut-turut 0,73 dan 1,19; indikator kedua 0,81 dan 0,9; indikator ketiga 0,67 dan 1,19. Hal tersebut dikarenakan jumlah peserta didik pada kedua kelas tersebut terpaut sangat jauh selisihnya 5 orang dari 47 jumlah peserta didik. Kemudian pada kelas kontrol lebih banyak peserta didik yang selalu rutin untuk mengikuti les/privat di tempat terdekatnya.

Setelah melakukan uji secara statistik terhadap hasil pretest kemampuan berpikir kritis matematis, diperoleh hasil Sig. (2 pihak) dengan jumlah peserta didik 47 yaitu 0,019 maka 
$\mathrm{H}_{0}$ ditolak. Artinya data hasil pretest menunjukkan bahwa terdapat perbedaan kemampuan berpikir kritis matematis peserta didik pada kelas eksperimen dan kelas kontrol.

b. Peningkatan Kemampuan Berpikir Kritis Matematis Peserta Didik

Peningkatan akan terlihat ketika pembelajaran dengan strategi REACT pada kelas Eksperimen dan pembelajaran konvensional pada kelas kontrol selama tiga pertemuan sudah terlaksana. Maka akan terjadi peningkatan kemampuan berpikir kritis matematis pada kedua kelas tersebut. Data hasil tes peningkatan (N-Gain) kemampuan berpikir kritis matematis peserta didik dari kedua kelas setelah mengikuti pembelajaran dapat dilihat pada tabel berikut.

Tabel 8 Data Hasil Peningkatan (N-Gain) Kemampuan Berpikir Kritis Matematis

Kelas Eksperimen

Kelas Kontrol

\begin{tabular}{cccccccc}
\hline $\begin{array}{c}\text { Jumlah } \\
\text { Peserta } \\
\text { didik }\end{array}$ & $\begin{array}{c}\text { Nilai } \\
\text { Min. }\end{array}$ & $\begin{array}{c}\text { Nilai } \\
\text { Max. }\end{array}$ & $\begin{array}{c}\text { Rata- } \\
\text { rata }\end{array}$ & $\begin{array}{c}\text { Jumlah } \\
\text { Peserta } \\
\text { didik }\end{array}$ & $\begin{array}{c}\text { Nilai } \\
\text { Min. }\end{array}$ & $\begin{array}{c}\text { Nilai } \\
\text { Max. }\end{array}$ & $\begin{array}{c}\text { Rata- } \\
\text { rata }\end{array}$ \\
\hline 26 & 0 & 1,00 & 0,49 & 21 & 0 & 1,00 & 0,26 \\
\hline
\end{tabular}

Berdasarkan tabel data tersebut, rata-rata hasil peningkatan (N-Gain) kemampuan berpikir kritis matematis peserta didik diperoleh pada kelas eksperimen sebesar 0,49 dengan kategori sedang dan pada kelas kontrol sebesar 0,26 dengan kategori kurang. Dari data di atas, menjelaskan bahwa kemampuan berpikir kritis matematis pada kelas eksperimen lebih baik secara signifikan dari pada kelas kontrol.

Peneliti menjabarkan pada setiap indikator kemampuan berpikir kritis peserta didik dengan nilai berkisar 1-4 pada setiap indikatornya sudah cukup meningkat. Indikator pertama rata rata kedua kelas eksperimen dan kontrol berturut-turut 2,65 dan 0,88; indikator kedua 3,35 dan 3,21; indikator ketiga 2,81 dan 2,43. Data tersebut menunjukkan sudah ada peningkatan pada kedua kelas. Namun, pada hasil peningkatan atau dari data posttest kelas eksperimen mengungguli pada setiap indikatornya. Hal tersebut dikarenakan kelas eksperimen mendapatkan perlakuan yang berbeda dari kelas kontrol yaitu memperoleh pemelajaran dengan menerapkan strategi REACT.

Kemudian peneliti melakukan uji statistik pada data posttest untuk melihat perbedaan peningkatan secara signifikan, diperoleh hasil Sig. (2 pihak) dengan jumlah peserta didik 47 yaitu 0,011 karena pada penelitian ini memihak pada kelas eksperimen yang diberikan perlakuan, maka hasil uji statistik ini dibagi dua menjadi $\frac{0,011}{2}$ sehingga menjadi 0,005 maka 
$\mathrm{H}_{0}$ ditolak. Artinya pada taraf kepercayaan 95\% dapat digeneralisasikan bahwa rata-rata skor N-Gain kemampuan berpikir kritis matematis peserta didik kelas eksperimen lebih baik dari pada kelas kontrol. Dengan demikian, peningkatan kemampuan berpikir kritis matematis kelas eksperimen peningkatannya lebih baik secara signifikan dari pada kelas kontrol.

Berdasarkan hasil peningkatan terdapat beberapa kesalahan peserta didik dalam menjawab pertanyaan berikut analisis jawaban peserta didik. Hasil posttest yang diperoleh, rata-rata skor setiap indikator secara berurutan, yang pertama terdapat pada indikator kedua, yang kedua terdapat pada indikator ketiga, dan yang terakhir rata-rata terkecil dari ketiga indikator adalah indikator nomor satu. Gambar dibawah merupakan gambar hasil pekerjaan peserta didik yang menjawab benar pada posttest kemampuan berpikir kritis matematis soal nomor 1 .

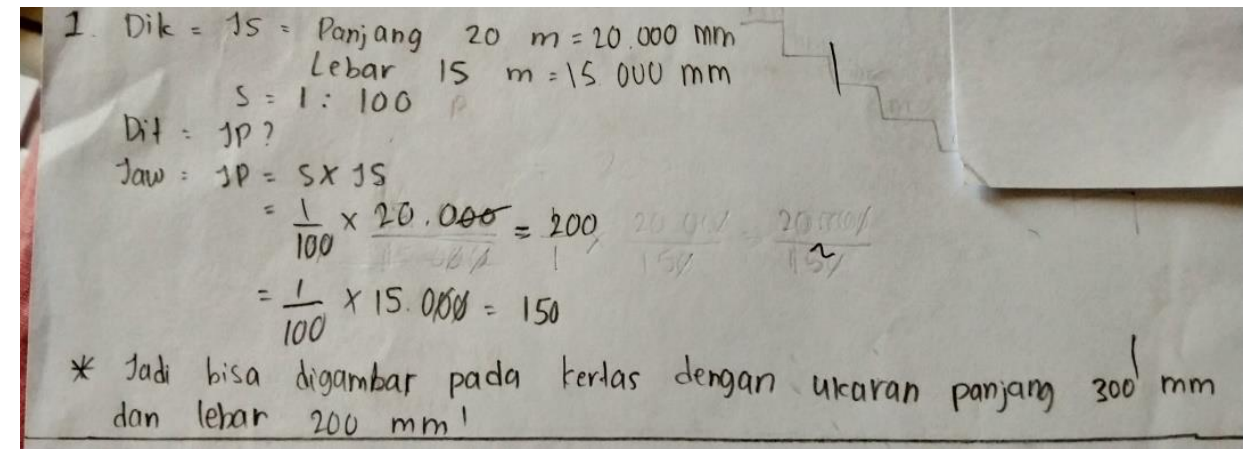

Gambar 1 Jawaban Peserta Didik 1 Soal Nomor 1

Berdasarkan gambar tersebut, dapat dilihat bahwa peserta didik sudah mampu membangun keterampilan dasar (basic support). Hal tersebut ditunjukkan oleh peserta didik dengan menuliskan rumus Jarak Peta (JP) dengan benar serta mengoperasikannya dengan tepat pula. Kemudian peserta didik juga sudah mampu menjawab soal dengan sistematika yang benar dari mulai diketahui, ditanyakan, dijawab sampai memberikan kesimpulan.

Berdasarkan posttest kemampuan berpikir kritis matematis, namun ada beberapa peserta didik yang menjawab kurang tepat. Gambar dibawah merupakan contoh jawaban peserta didik yang kurang tepat. 


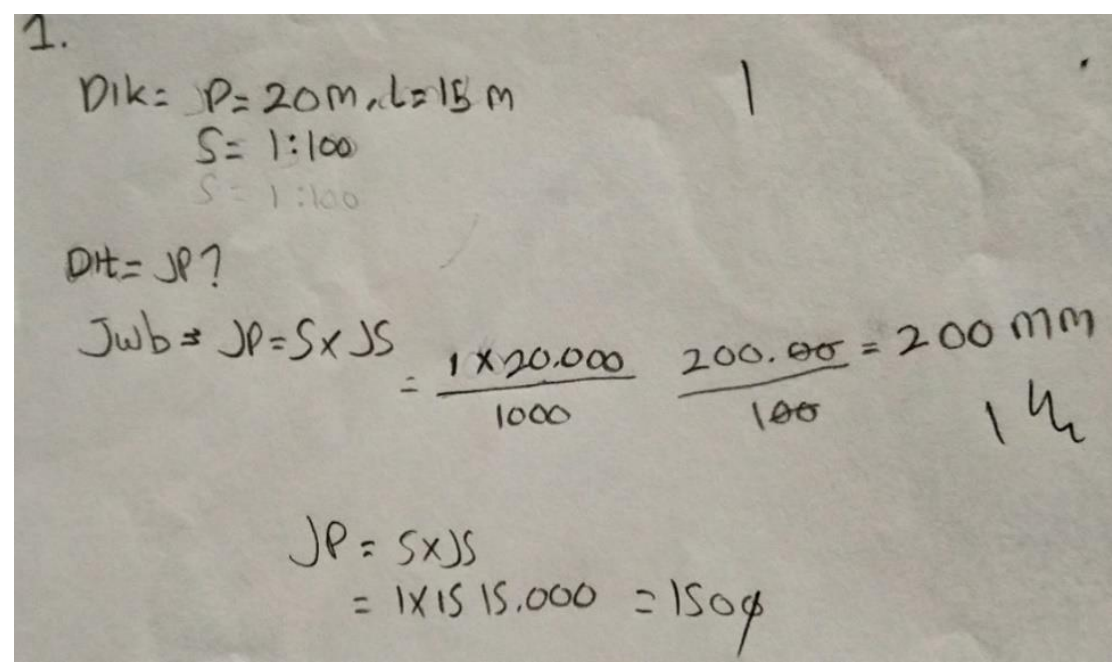

Gambar 2 Jawaban Peserta Didik 2 Soal Nomor 1

Berdasarkan gambar tersebut, dapat dilihat bahwa peserta didik masih belum bisa membangun keterampilan dasar (basic support). Hal ini ditunjukkan oleh peserta didik dalam mengoperasikan rumus yang telah diaplikasikan dengan angka-angka (pada soal nomor 1). sedangkan pada soal nomor 5 peserta didik belum mampu menuliskan rumus dan mengaplikasikannya dengan angka-angka yang telah diketahui pada soal tersebut.

Hal ini juga terjadi pada penelitian yang dilakukan oleh (Rahmaton, 2018) yang menyatakan bahwa faktor kemampuan peserta didik dalam membangun keterampilan dasar dalam matematika masih kesulitan. Peserta didik belum terbiasa dengan pembelajaran yang mengalami sendiri serta menemukan sendiri pada suatu konsep matematika. Tetapi pada soal nomor 1, peserta didik sudah mampu menuliskan rumus skala. Namun ketika proses pengoperasian rumus tersebut mengalami kesalahan dalam menempatkan skala serta jarak sebenarnya yang diketahui. Ketika rumus JP $=\mathrm{S} \times \mathrm{JS}$ sudah benar namun ketika memasukan hal yang telah diketahui peserta didik kurang tepat memasukkannya yang seharusnya jawabannya itu adalah $\frac{1}{100} \times 20.000$, akan tetapi peserta didik menuliskan $\frac{1 \times 20.000}{1.000}$. Jenis kesalahan ini sejalan dengan penelitian (Syahbana, 2012) yang menyatakan bahwa peserta didik sudah paham terhadap konsep dari rumus skala namun kurang tepat dalam mengaplikasikan rumus ke dalam angka yang telah diketahui pada soal.

Sementara itu, peningkatan kemampuan berpikir kritis matematis kedua tertinggi terletak pada indikator ketiga yaitu Membangun simpulan (inference). Indikator ketiga terdapat pada soal nomor 2 dan soal nomor 4. Gambar dibawah merupakan salah sat pekerjaan peserta didik yang menjawab benar pada saat diberikan soal posttest indikator ketiga pada nomor soal 2 dan 4. 


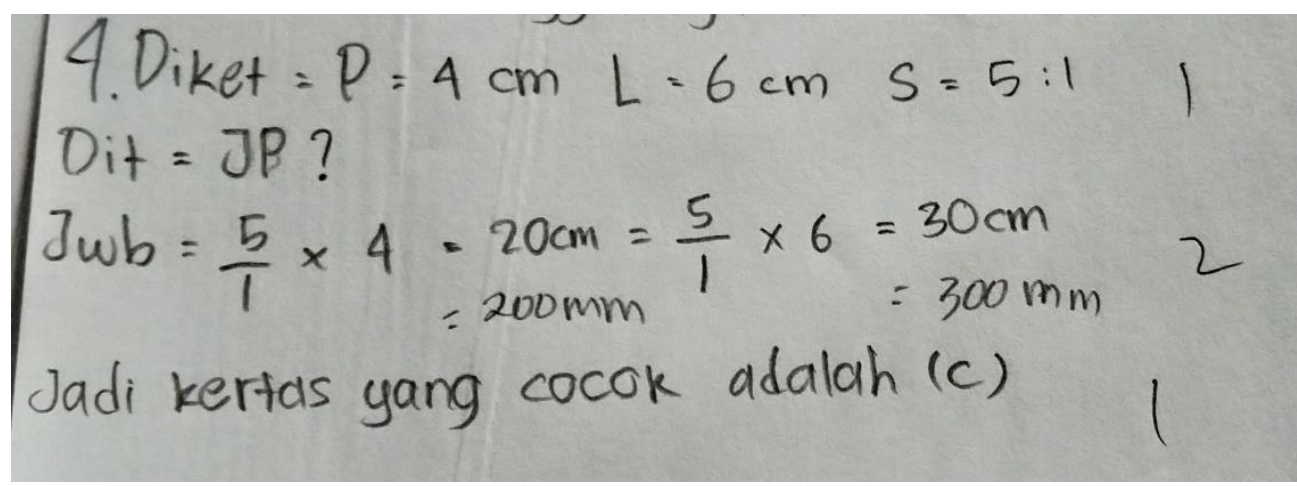

Gambar 3 Jawaban Peserta Didik 3 Soal Nomor 4

Berdasarkan gambar tersebut, dapat dilihat bahwa peserta didik sudah mampu membangun simpulan (inference). Hal tersebut ditunjukkan oleh peserta didik dengan memberikan kesimpulan pada setiap jawabannya dan peserta didik mampu menyelesaikan permasalahan yang ada pada soal. Pertama peserta didik sudah mampu memilah mana yang harus dituliskan pada informasi yang dibutuhkan (diketahui) sehingga tidak semua informasi dimasukkan. Kemudian peserta didik menghitung satu persatu panjang dan lebarnya dan peserta didik sudah mampu mengkonversi satuan panjang dari $\mathrm{cm}$ ke $\mathrm{mm}$ dengan tepat.

Berdasarkan hasil posttest kemampuan berpikir kritis matematis, terdapat pula beberapa peserta didik yang menjawab kurang tepat. Gambar berikut merupakan beberapa jawaban peserta didik yang kurang tepat.

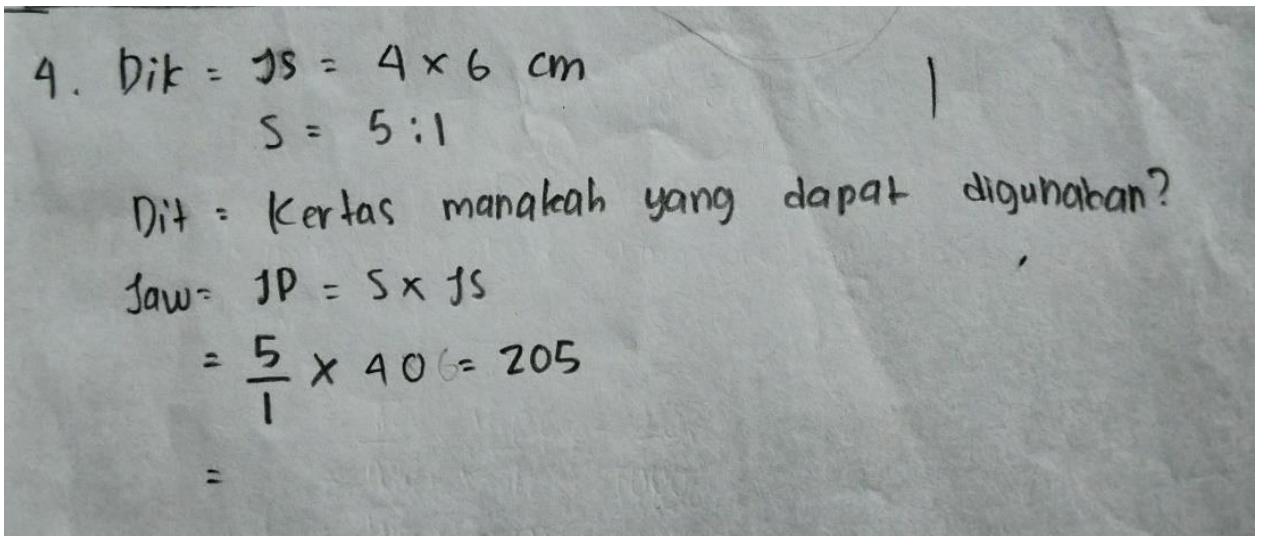

\section{Gambar 4 Jawaban Peserta Didik 4 Soal Nomor 4}

Berdasarkan gambar tersebut, dapat dilihat dan ketahui bahwa peserta didik belum mampu untuk membangun kesimpulan pada permasalahan matematika yang diberikan. Hal ini juga terjadi pada penelitian (Gradini \& Noviani, 2018) yang menyatakan bahwa hal-hal yang menyebabkan kemampuan peserta didik dalam membangun kesimpulan dalam permasalahan matematika. Peserta didik belum terbiasa ketika diberikan suatu permasalahan 
dalam soal matematika khususnya terkadang lupa bahkan tidak langsung diberikan kesimpulan ketika menjawab soal karena peserta didik beranggapan bahwa sudah menemukan jawaban yang telah mereka cari.

Kemudian peningkatan kemampuan berpikir kritis matematis terendah terdapat pada indikator pertama yaitu memberikan penjelasan sederhana (elementary clarification). Indikator pertama terdapat pada soal nomor 3. Berikut adalah gambar salah satu pekerjaan peserta didik yang menjawab benar pada posttest indikator pertama nomor soal 3 .

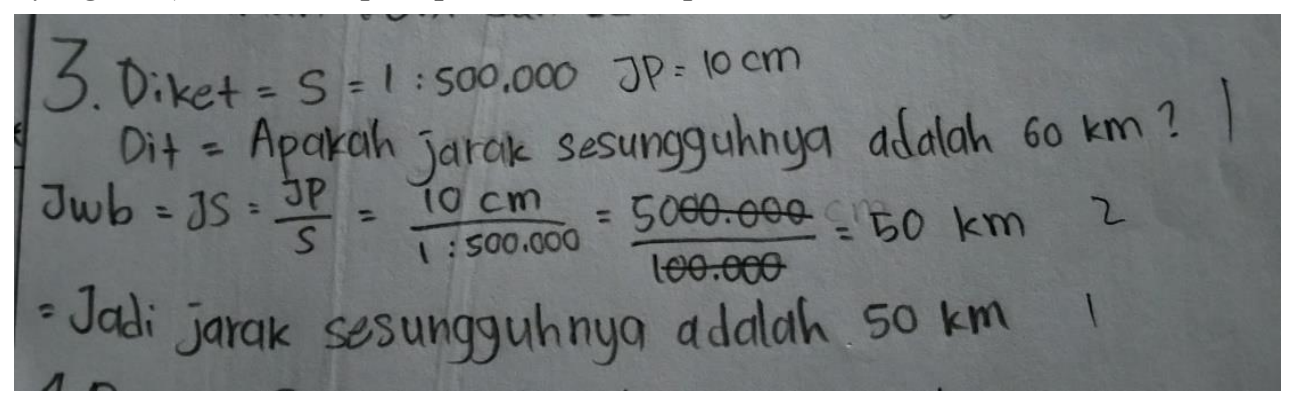

\section{Gambar 5 Jawaban Peserta Didik 5 Soal Nomor 3}

Berdasarkan gambar tersebut, dapat diketahui bahwa peserta didik sudah mampu memberikan penjelasan secara sederhana dalam permasalahan soal matematika. Hal tersebut ditunjukkan dengan peserta didik mampu menuliskan informasi yang tertera di dalam soal serta menuangkannya ke dalam jawaban persoalan. Pertama peserta didik diharuskan untuk menuliskan informasi yang ada dalam soal. Kemudian mengaplikasikan ke dalam rumus terkait yang telah mereka ketahui. Setelah itu peserta didik mengkonversi satuan yang menjadi jawaban dari rumus yang telah dituliskan dari $\mathrm{cm}$ ke $\mathrm{km}$, karena dari $\mathrm{cm}$ ke km itu dibagi 100.000 maka $\frac{5.000 .000}{100.000}$ hasilnya adalah $50 \mathrm{~km}$. Peserta didik telah mampu menuliskan satuan tersebut dengan tepat.

Berdasarkan hasil posttest kemampuan berpikir kritis matematis, terdapat pula peserta didik yang menjawab kurang tepat. Gambar berikut adalah salah satu contoh peserta didik yang menjawab kurang tepat. 


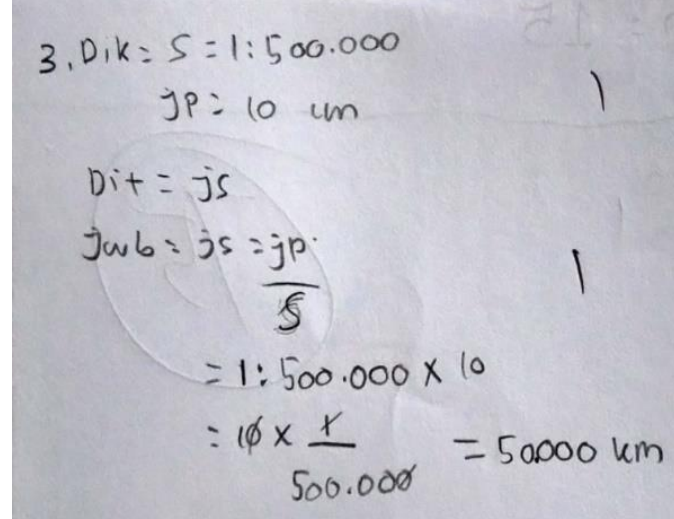

\section{Gambar 6 Jawaban Peserta Didik 6 Soal Nomor 3}

Berdasarkan gambar tersebut, dapat dilihat bahwa peserta didik sudah mampu menuliskan beberapa penjelasan secara sederhana dalam soal yang diberikan. Akan tetapi, unsur-unsur yang diketahui ditanyakan dalam jawaban kurang tepat. Kemudian dalam proses penyelesaian, peserta didik masih kurang tepat dalam menuliskan hasil akhir operasi perkalian dan pembagian tersebut.

Berdasarkan analisis yang telah dilakukan terhadap hasil posttest kemampuan berpikir kritis matematis di kelas eksperimen dan kelas kontrol, diperoleh hasil bahwa peserta didik yang berada di kelas eksperimen lebih baik daripada kelas kontrol. Hal ini serupa dengan penelitian yang dilakukan oleh (Herawati, 2012) yang memperoleh kesimpulan bahwa peningkatan kemampuan berpikir kritis matematis peserta didik yang diterapkan strategi pembelajaran REACT lebih baik daripada peserta didik yang diterapkan pembelajaran konvensional. Selain itu, hasil penelitian lain yang dilakukan oleh (Ihsani et al., 2020) memperoleh kesimpulan bahwa rata-rata hasil tes kemampuan berpikir kritis matematis peserta didik yang memperoleh pembelajaran dengan menggunakan strategi REACT lebih baik dibandingkan rata-rata hasil tes kemampuan berpikir kritis matematis peserta didik yang memperoleh model pembelajaran langsung.

Secara umum kemampuan yang diukur oleh beberapa peneliti mengatakan bahwa pembelajaran dengan menerapkan strategi REACT lebih baik dari pada pembelajaran konvensional atau yang sering dilaksanakan pada kelas tersebut. Hal tersebut disebabkan oleh adanya strategi yang diterapkan cukup cocok pada kelas eksperimen khususnya. Kelas tersebut mendapatkan pelakuan yang berbeda, diantaranya kelas dirancang menjadi berkelompok dengan anggota 4-5 orang setiap kelompoknya. Kemudian diberikan Lembar Kerja Peserta Didik (LKPD) untuk membantu peserta didik dalam penyelesaian masalah yang ditemukan sehingga menjadi sebuah kesimpulan. Kemudian peserta didik dituntut untuk mengalaminya secara langsung contohnya mengukur lapangan menggunakan 
meteran secara berkelompok dan bergantian, mengukur peta menggunakan penggaris dan lain sebagainya. Sehingga peserta didik menemukan pemahaman yang cukup untuk mencapai sebuah rumus dan dapat diterapkan untuk menghitung dalam penyelesaian masalah soal matematika bahkan dapat diterapkan dalam kehidupan sehari-hari.

Kegiatan relating atau menghubungkan, guru menghubungkan konsep yang dipelajari peserta didik dengan hal-hal yang dekat dengan kehidupan peserta didik. Menurut (Mugita et al., 2019) matematika tidak menerima generalisasi berdasarkan pengamatan (induktif), tapi harus berdasarkan pembuktian deduktif. Pembuktian deduktif yang dimaksud adalah dalam mengembangkan suatu pemikiran terdapat tahap-tahap permulaan yang membutuhkan praktik untuk peserta didik mencobanya secara langsung. Dalam pembelajaran skala, guru menghubungkan benda-benda seperti skala peta, denah, serta globe dan lainnya supaya peserta didik lebih mudah memahami penjelasan dari guru. Guru pun menggunakan LKPD mengenai skala agar mempermudah peserta didik dalam memahami skala. LKPD tersebut diberikan kepada setiap kelompok supaya peserta didik dapat melakukan kegiatan experiencing atau mengalami. Menurut (Mala et al., 2019) tahap experiencing ini penting karena peserta didik bereksplorasi sehingga menemukan sendiri suatu konsep yang baru dipelajari.

Proses applying dari konsep yang telah diketahui melalui kegiatan experiencing kemudian diaplikasikan dalam bentuk pengerjaan soal-soal yang harus diselesaikan secara cooperating (Mawarni et al., 2019). Sejalan dengan pendapat Association for the Advancement of Science (Yupita et al., 2014), proses pembelajaran yang terbaik adalah ketika peserta didik memiliki kesempatan untuk mengekspresikan ide-ide mereka dan mendapatkan umpan balik dari teman-teman mereka dalam mencari dan menemukan konsep sendiri dengan bantuan LKPD. Dalam kelompok tersebut peserta didik dapat bertukar pemikiran dan leluasa menyampaikan argumen yang ia miliki. Selain itu, peserta didik juga dilatih untuk menerima pemikiran orang lain yang mungkin saja berbeda dengan pemikiran dirinya sendiri. Dengan menerima pemikiran orang lain, pengetahuan yang ia miliki menjadi bertambah dan semakin matang. Selain itu, (Nisa et al., 2018) menjelaskan interaksi dengan lingkungan memungkinkan peserta didik memperbaiki pemahamannya dan memperkaya pengetahuannya melalui tanya jawab dan berdiskusi dengan kelompok belajarnya.

Kegiatan selanjutnya adalah transferring. Pada kegiatan transferring, peserta didik harus mampu mentransfer pengetahuan yang telah didapatkan pada konteks yang berbeda. Misalkan berbeda dalam masalah penyelesaiannya, dalam hal redaksi kalimatnya dan dalam kehidupan sehari-hari yang memerlukan penyelesaian hal tersbut. Pada pelaksanaannya di kelas guru memberikan soal latihan/evaluasi kepada peserta didik dan harus dikerjakan dengan pemahaman yang telah didapatkan kemudian guru sebagai fasilitator dan mengarahkan peserta didiknya. 
Kegiatan yang terdapat pada strategi REACT tentunya tidak ditemukan pada pembelajaran di kelas kontrol yang menggunakan pembelajaran konvensional. Dalam pembelajaran konvensional, pembelajaran dimulai dengan mengamati benda di sekitar peserta didik yang berhubungan dengan skala. Kemudian memberi kesempatan kepada peserta didik untuk bertanya. Guru kemudian menjelaskan materi pembelajaran, setelah itu memberi soal latihan secara individu kemudian membahasnya secara bersama-sama. Proses pembelajaran yang terjadi di kelas kontrol dengan menerapkan pembelajaran konvensional masih kurang efektif untuk meningkatkan kemampuan berpikir kritis karena dalam pembelajaran konvensional sifatnya masih berpusat pada guru dan peserta didik kurang aktif terlibat dalam proses pembelajaran. Peserta didik tidak menemukan sendiri pengetahuan barunya, tetapi langsung dijelaskan oleh guru. Selain itu, dalam pengerjaan soal dilakukan secara individu sehingga tidak adanya proses pertukaran pengetahuan dari teman yang lain.

Berdasarkan uraian tersebut, dapat disimpulkan bahwa kemampuan berpikir kritis matematis peserta didik yang mendapat pembelajaran dengan strategi REACT pada pokok bahasan skala lebih baik dari peserta didik yang mendapatkan pembelajaran konvensional. Dengan demikian, strategi REACT dapat meningkatkan kemampuan berpikir kritis matematis peserta didik MI.

\section{SIMPULAN}

Kemampuan awal berpikir kritis matematis peserta didik pada pokok bahasan skala pada kelas eksperimen dan kelas kontrol memiliki perbedaan yang signifikan. Hal ini terlihat dari hasil rata-rata pemberian pretest pada kelas eksperimen 14,2 dan kelas kontrol 20,7 serta berada dalam kategori sangat rendah.

Peningkatan kemampuan berpikir kritis matematis peserta didik pada pokok bahasan skala di kelas eksperimen lebih baik secara signifikan dari pada kelas kontrol. Hal ini terlihat dari hasil rata-rata peningkatan pada kelas eksperimen 0,49 dan kelas kontrol 0,26. Kemudian hasil ratarata posttest kelas eksperimen 55,0 dan kelas kontrol 40,8. Dengan demikian strategi REACT mampu meningkatkan kemampuan berpikir kritis matematis peserta didik. Hal ini dikarenakan ketika mengikuti pembelajaran dengan strategi REACT, belajar dalam sebuah kelompok sehingga terjalin sebuah komunikasi baik secara lisan maupun tulisan. Semoga penelitian ini dapat menambah wawasan terkait strategi mengajar di dalam kelas serta dapat meningkatkan kemampuan matematis peserta didik untuk jenjang MI khususnya, umumnya untuk semuanya.

\section{DAFTAR PUSTAKA}

Abdullah, In Hi. (2013). Delta-Pi: Jurnal Matematika Dan Pendidikan Matematika Vol. 2, No. 1, April 2013 ISSN 2089-855X. Jurnal Matematika Dan Pendidikan Matematika, 2(1), 66-75. 
Abidin, Y. (2015). Pembelajaran Multiliterasi (Sebuah Jawaban Atas Tantangan Pendidikan Abad 21). Bandung.

Adiwijaya, I. G. (2015). Pengarub Penerapan Model Problem Based Learning Dengan Metode Scientific Debate Terhadap Kemampuan Berpikir Kritis Siswa. Repository, 1-8.

Depdiknas. (2013). Kajian Kebijakan Kurikulum Mata Pelajaran Matematika. Jakarta: Pusat Kurikululum Balitbang Depdiknas.

Devi, N. L. P. L. (2015). Kemampuan Berpikir (Sppkb) Terhadap Kemampuan Berpikir Kritis Siswa Smp Oleh : Proceedings Seminar Nasionl FMIPA UNDIKSHA V, 7-12.

Durotulaila, A. H., Masykuri, M., \& Mulyani, B. (2014). Pengaruh Model Pembelajaran REACT (Relating, Experiencing, Applying, Cooperating, Transfering) Dengan Metode Eksperimen Dan Penyelesaian Masalah Terhadap Prestasi Belajar Ditinjau Dari Kemampuan Analisis Siswa. 3(4), 66-74.

Gradini, E., \& Noviani, J. (2018). Calon Guru Matematika Melalui Level Hots Marzano. Eduma, 7(2). Hamdani. (2011). Dasar-Dasar Pendidikan. Bandung: Pustaka Setia.

Herawati, L. (2012). Pembelajaran Melalui Strategi React Untuk. Meningkatkan Kemampuan Pemahaman Dan Berpikir Kritis Matematis Siswa Smk.

Ihsani, A. Z., Langitasari, I., \& Affifah, I. (2020). Penerapan Model Pembelajaran React Terhadap Keterampilan Berpikir Kritis Siswa Pada Konsep Kelarutan Dan Hasil Kali Kelarutan. 14(1), 24982511.

Johar, S. M. R. F. R. (2013). Peningkatkan Kemampuan Pemahaman Dan Penalaran Matematis Melalui Pendekatan Kontekstual. 47-54.

Kemendikbud. (2017). Mengenai TIMMS. Pusat Penelitian Badan Penelitian dan Pengembangan.

Mahmud, M. R. (2011). Pembelajaran Kontekstual Strategi REACT (Relating, Experiencing, Applying, Cooperating, Transfering) untuk meningkatkan Kemampuan Pemahaman Matematis Peserta Didik. Bandung: Tidak Dipublikasikan.

Mala, P., Eko, S., \& Nengah, M. (2019). Pengarub Lkpd Dengan Strategi React Pada Materi Berpikir Kreatif Peserta Didik. Jurnal Ilmiah Penelitian Dan Pembelajaran Fisika, 5(2), 58-66.

Mawarni, J., Syahbana, A., \& Septiati, E. (2019). Pengarub Strategi Pembelajaran React Terhadap Kemampuan Berpikir Kritis Ditinjau Dari Kemampuan Awal Siswa Smp. Indiktika: Jurnal Inovasi Pendidikan $\quad$ Matematika, 172. Https://Doi.Org/10.31851/Indiktika.V1i2.3190

Mugita, A. R., Nurjamil, D., \& Rustina, R. (2019). Peningkat An Kemampua N Koneks I D An Komunikas I Matem Atis Peser Ta Didi K Melalu I Mode L Probl Em. 1(1).

Nisa, F. C., Lesmono, A. D., \& Bachtiar, R. W. (2018). Model Pembelajaran Kontekstual Relating, Experiencing, Applying, Cooperating, And Transferring (React) Dengan Simulasi Virtual Dalam 
Pembelajaran Fisika Di Sma (Materi Momentum, Impuls Dan Tumbukan Kelas X Sman 2 Jember). Jurnal Pembelajaran Fisika, 7(1), 8. Https://Doi.Org/10.19184/Jpf.V7i1.7219

Paradesa, R. (2016). Kemampuan Berpikir Kritis Matematis Mahasiswa Melalui Pendekatan Kontruktivisme Pada Matakuliah Matematika Kenangan. 1(2), 306-325.

Pratiwi, I. M. (2014). Penerapan Strategi REACT untuk Meningkatkan Kemampuan Komunikasi Matematis Peserta Didik Sekolah Dasar Materi Bangun Ruang Sederhana. Skripsi UPI: Tidak Diterbitkan.

Pusipta Aini, Firda Nurul, Suprakarti, S. P. (2015). Penerapan Strategi React Relating, Experiencing, Applying,Cooperating, Transfering) Untuk Meningkatkan Kemampuan Koneksi Matematis Siswa Pada Pokok Bahasan Bangun Datar Di Kelas Vii-2 Smp Negeri 47 Jakarta. 67-75.

Rahmaton. (2018). Meningkatkan Kemampuan Berpikir Kritis Matematis Melalui Strategi React Pada Siswa Kelas Vii Mtsn 6 Aceh Besar.

Ratna Purwati, Hobri, A. F. (2016). Analisis Kemampuan Berpikir Kritis Siswa Dalam Menyelesaikan Masalah Persamaan Kuadrat Pada Pembelajaran Model Creative Problem Solving. 7.

Ruseffendi, E. (2010). Dasar-dasar Penelitian Pendidikan dan Bidang Non-Eksakta Lainnya. Bandung: Tarsito.

Suandito, B. (2017). Bukti Informal Dalam Pembelajaran Matematika Billy. 13-24.

Sugiyono. (2017). Metode Penelitian Pendidikan Pendekatan Kuantitatif. Bandung: Alfabeta.

Suherman, E. (2011). Strategi Pembelajaran Matematika Kontemporer. Alfabeta.

Syahbana, A. (2012). Peningkatan Kemampuan Berpikir Kritis Matematis Siswa Smp Melalui Pendekatan Contextual Teaching And Learning. Edumatica, 02(April), 45-57.

Utami, R. (2013). Model Pembelajaran Berbasis Masalah Dengan Langkah Penyelesaian Berdasarkan Polya Dan Krulik-Rudnick Ditinjau Dari Kreativitas Siswa. 1(1).

Yahya, M. (2010). Pengantar Pendidikan. Bandung: Solo Press.

Yudhanegara, K. E. (2017). Penelitian Pendidikan Matematika. Bandung: Refika Aditama.

Yupita, S., Fauziah, A., \& Luthfiana, M. (2014). Pengaruh Strategi React Relating, Experiencing, Applying, Coorperating, Transfering) Terhadap Kemampuan Berpikir Kritis Matematis Siswa Kelas Xi Ipa Sma Negeri 5 Lubuklinggau Tabun Pelajaran 2015/2016. Stkip-Pgri Lubuklinggau, 2(1), $1-13$. 